\title{
Physicochemical and Phytochemical Standardization of Siddha Herbal Drug Formulation- Parangichakkai Chooranam
}

\author{
S. Kalaivani ${ }^{1 *}$, M. Meenakshi Sundaram ${ }^{2}$, R. Meenakumari ${ }^{3}$
}

\begin{abstract}
${ }^{1}$ Third year PG Scholar, Department of Kuzhandahai Maruthuvam, National Institute of Siddha, Chennai- Trichy Hwy, near Government Hospital, Tamabaram Sanatorum, Chennai, Tamil Nadu 600047, India

${ }^{2}$ Professor and Head of the Department, Department of Kuzhandahai Maruthuvam, National Institute of Siddha, Chennai- Trichy Hwy, near Government Hospital, Tamabaram Sanatorum, Chennai, Tamil Nadu 600047, India

${ }^{3}$ Director and professor, National Institute of Siddha, Chennai- Trichy Hwy, near Government Hospital, Tamabaram Sanatorum, Chennai, Tamil Nadu 600047, India
\end{abstract}

DOI: $10.36347 /$ sjams.2020.v08i10.032

| Received: 04.10.2020 | Accepted: 19.10.2020 | Published: 26.10.2020

*Corresponding author: S. Kalaivani, PG scholar

Abstract

Original Research Article

The Siddha system of medicine is capable of treating all types of skin diseases. This trial medicine Parangichakkai chooranam is the sasthric preparation. The aim of the present study is investigating the phytochemical and physiochemical analysis of the trial drug Parangichakkai chooranam. Phytochemical analysis, heavy metal analysis and physiochemical parameters such as ash values, extract values, loss of drying were determined as protocol. The physiochemical parameters such as the total as value was found to be $14.3 \pm 1.054$, insoluble ash value $0.066 \pm 0.041$, loss of drying $11.5 \pm 0.9$ and water-soluble extract $5.213 \pm 0.9$, alcohol soluble extract found to be $13.8 \pm 2.553$. the phytochemical analysis of different extracts gave positive test for Alkaloids, flavonoids, steroids, coumarin, phenol, tannin, protein, sugar. The heavy metal analysis showed the presence of heavy metal mercury at $0.027 \mathrm{ppm}$, which may be less than the recommended limit. The results obtained indicate that the drug is of standard quality and can be used as reference standard.

Keywords: Parangichakkai chooranam, Siddha medicine, Physicochemical analysis, Herbal drug.

Copyright $\left({ }^{\circ} 2020\right.$ The Author(s): This is an open-access article distributed under the terms of the Creative Commons Attribution 4.0 International License (CC BY-NC 4.0) which permits unrestricted use, distribution, and reproduction in any medium for non-commercial use provided the original author and source are credited.

\section{INTRODUCTION}

A siddha system of medicine is the oldest holistic management system with meticulously documented medicines and being practiced by large population in south India. Herbal traditional medicines have gained considerable momentum worldwide during the past decade and play paramount role in health care programme especially in developing countries. According to W.H.O nearly $80 \%$ of population of developing countries rely on traditional medicines for most of their ailments. Ancient siddha literatures are well provided with reference on the use of herbs with medicinal properties. Balakarappan has been described in siddha literature as the diseases occurring in children. According to the siddha textbook 'Kuzhandhai Maruthuvam (Balavagadam) [1]. Atopic dermatitis in infants and children the rash usually occurs on the scalp, back of the knees and cheeks, elbows. It is character by dry, itchy, red and cracked skin, which can sometimes ooze fluid and bleed. Parangichakkai chooranam comprises of 21 herbal ingredients like Smilax china, Zingiber officinale, Piper longum, Elettaria cardamomum, Embelia ribes, Cinnamomum verum, Carum copiticum, Hyoscyamus niger, Plumbago zeylanica, Alpinia officinarum, Piper longum, Alpinia galangal, Clerodendrum serratum, Coriandrum sativum, Cuminum cyminum, Nigella sativa, Glycyrrhiza glabra, Vettiveria zizanioides, Plectranthus vettiveroides, Cyperus rotundus, Kaempferia galangal. The herbal ingredients of parangichakkai chooranam possess antiinflammatory, anti-microbial, anti-bacterial, antiimmune and allergic activity. which have the tendency to cure skin diseases. The present study is to investigate the physiochemical and phytochemical and heavy metal analysis of the trial drug parangichakkai chooranam sasthric preparation which is mentioned in siddha text book of chikicha rathna deepam.

Ingridients of parangichakkai chooranam [2, 3]
$\begin{array}{lll}\text { 1. } & \text { Parangichakkai (Smilax china) } & (105 \mathrm{gm})[4] \\ \text { 2. } & \text { Sukku (Zingiber officinale) } & (12.6 \mathrm{gm}) \\ \text { 3. } & \text { Thippli (Piper longum) } & (12.6 \mathrm{gm}) \\ \text { 4. } & \text { Elam (Elettaria cardamomum) } & (12.6 \mathrm{gm}) \\ \text { 5. } & \text { Vaaivilangam (Embelia ribes) } & (12.6 \mathrm{gm}) \\ \text { 6. } & \text { Sannalavangapattai (Cinnamomum verum) } \\ & (12.6 \mathrm{gm})\end{array}$


7. Omam (Carum copticum) $(12.6 \mathrm{gm})$

8. Kurosani omam (Hyoscyamus niger) (12.6gm)

9. Chitramoola verpattai (Plumbago zeylanica) (12.6gm)

10. Chitrarathai (Alpinia officinarum) (12.6gm)

11. Thippliver (Piper longum) (12.6gm)

12. Perarathai (Alpinia galanga) (12.6gm)

13. Sirutheku (Clerodendrum serratum) (12.6gm)

14. Dhaniya (Coriandrum sativum) (12.6gm)

15. Seeragam (Cuminum cyminum) (12.6gm)

16. Karunjeeragam (Nigella sativa) (12.6gm)

17. Adhimaduram (Glycyrrhiza glabra) (12.6gm)

18. Vettiver (Vetiveria zizanioides) (12.6gm)

19. Vilamichuver (Plectranthus vettiveroides) (12.6gm)

20. Muthakasu (Cyperus rotundus) (12.6gm)

21. Kichilikizangu (Kaempferia galanga) (12.6gm)

\section{METHOD OF PREPARATION}

All the above ingredients are purified as per book Sarakku suthi muraigal and are grinded separately as fine powder. Then the powder is mixed together with equal amount of white sugar. Prepared medicine is stored in clean and dry glass container.

\section{Dosage}

5-6 years $-1.3 \mathrm{gm}$

7- 12 years $-2 \mathrm{gm}$, twice a day, after food

Vehicle: Ghee

Duration of Treatment: 45 days

Physiocochemical Analysis [5, 6]:

Table-1: Sample Description

\begin{tabular}{|l|l|}
\hline State & Solid \\
\hline Nature & Coarse powder \\
\hline Odor & Aromatic \\
\hline Touch & Slightly moistened \\
\hline Flow Property & Non free flowing \\
\hline Appearance & Pale Greenish brown \\
\hline
\end{tabular}

\section{Percentage Loss on Drying}

Test drug was accurately weighed in evaporating dish. The sample was dried at $105^{\circ} \mathrm{C}$ for 5 hours and then weighed.

\section{Determination of Total Ash}

Test drug was accurately weighed in silica dish and incinerated at the furnace with the temperature of $400{ }^{\circ} \mathrm{C}$ until it turns white in color which indicates absence of carbon. Percentage of total ash will be calculated with reference to the weight of air-dried drug.

\section{Determination of Acid Insoluble Ash}

The ash obtained by total ash test was boiled with $25 \mathrm{ml}$ of dilute hydrochloric acid for 6 mins. Then the insoluble matter was collected in crucible and washed with hot water and ignited to constant weight. Percentage of acid insoluble ash was calculated with reference to the weight of air-dried ash.

\section{Determination of Alcohol Soluble Extractive}

Test sample was macerated with $100 \mathrm{ml}$ of alcohol in a closed flask for twenty-four hours, shaking frequently during six hours and allowing it to stand for eighteen hours. Filter rapidly, taking precautions against loss of solvent, evaporate $25 \mathrm{ml}$ of the filtrate in a tared flat-bottomed shallow dish, and dry at $105^{\circ} \mathrm{C}$, to constant weight and weigh. Calculate the percentage of alcohol-soluble extractive with reference to the air-dried drug.

\section{Determination of Water-Soluble Extractive}

Test sample was macerated with $100 \mathrm{ml}$ of chloroform water in a closed flask for twenty-four hours, shaking frequently during six hours and allowing it to stand for eighteen hours. Filter rapidly, taking precautions against loss of solvent, evaporate $25 \mathrm{ml}$ of the filtrate to dryness in a tared flat-bottomed shallow dish, and dry at $105^{\circ} \mathrm{C}$, to constant weight and weigh. Calculate the percentage of water-soluble extractive with reference to the air-dried drug.

Table-2: Final Test report

\begin{tabular}{|l|l|l|}
\hline S. No & Parameter & Mean $(\mathbf{n}=3)$ SD \\
\hline 1. & Loss on Drying at $105^{\circ} \mathrm{C}(\%)$ & $11.5 \pm 0.9$ \\
\hline 2. & Total Ash $(\%)$ & $14.3 \pm 1.054$ \\
\hline 3. & Acid insoluble Ash $(\%)$ & $0.066 \pm 0.041$ \\
\hline 4. & Water soluble Extractive $(\%)$ & $5.213 \pm 0.91$ \\
\hline 5. & Alcohol Soluble Extractive $(\%)$ & $13.8 \pm 2.553$ \\
\hline
\end{tabular}

\section{Sterility Test by Pour Plate Method Objective}

The pour plate techniques were adopted to determine the sterility of the product. Contaminated / un sterile sample (formulation) when come in contact with the nutrition rich medium it promotes the growth of the organism and after stipulated period of incubation the growth of the organism was identified by characteristic pattern of colonies. The colonies are referred to as Colony Forming Units (CFUs).

\section{Methodology}

Test sample was inoculated in sterile petri dish to which about $15 \mathrm{~mL}$ of molten agar $45^{\circ} \mathrm{C}$ were added. Agar and sample were mixed thoroughly by tilting and swirling the dish. Agar was kept undisturbed for 10 minutes. Plates were then inverted and incubated at $37^{\circ}$ 
C for 24-48 hours and further extended for 72 hours for fungal growth observation. Grown colonies of organism was then counted and calculated for CFU.

\section{RESULT}

No growth / colonies were observed in any of the plates inoculates with the test sample.

Test for Specific Pathogen

\section{Methodology}

Test sample was directly inoculated in to the specific pathogen medium (EMB, DCC, Mannitol, Cetrimide) by pour plate method. The plates were incubated at $37^{\circ} \mathrm{C}$ for $24-72 \mathrm{~h}$ for observation. Presence of specific pathogen identified by their characteristic color with respect to pattern of colony formation in each differential media.

Table-3: Detail of Specific Medium and their abbreviation

\begin{tabular}{|l|l|l|}
\hline Organism & Abbreviation & Medium \\
\hline E-coli & EC & EMB Agar \\
\hline Salmonella & SA & Deoxycholate agar \\
\hline Staphylococcus Aureus & ST & Mannitol salt agar \\
\hline Pseudomonas Aeruginosa & PS & Cetrimide Agar \\
\hline
\end{tabular}

Table-4: Result of Specific pathogen

\begin{tabular}{|l|l|l|}
\hline Organism & Specification & Result \\
\hline E-coli & Absent & Absent \\
\hline Salmonella & Absent & Absent \\
\hline Staphylococcus Aureus & Absent & Absent \\
\hline Pseudomonas Aeruginosa & Absent & Absent \\
\hline
\end{tabular}

No growth / colonies were observed in any of the plates inoculated with the test sample.

\section{Heavy Metal Analysis by AAS}

Standard: $\mathrm{Hg}, \mathrm{As}, \mathrm{Pb}$ and $\mathrm{Cd}-$ Sigma

\section{Methodology}

Atomic Absorption Spectrometry (AAS) is a very common and reliable technique for detecting metals and metalloids in environmental samples. The total heavy metal content of the sample was performed by Atomic Absorption Spectrometry (AAS) Model AA 240 Series. In order to determination the heavy metals such as mercury, arsenic, lead and cadmium concentrations in the test item.

\section{Sample Digestion}

Test sample was digested with $1 \mathrm{~mol} / \mathrm{L} \mathrm{HCl}$ for determination of arsenic and mercury. Similarly, for the determination of lead and cadmium the sample were digested with $1 \mathrm{~mol} / \mathrm{L}$ of $\mathrm{HNO} 3$.

\section{Standard Reparation}

As \& Hg- $100 \mathrm{ppm}$ sample in $1 \mathrm{~mol} / \mathrm{L} \mathrm{HCl}$

$\mathrm{Cd} \& \mathrm{~Pb}-100 \mathrm{ppm}$ sample in $1 \mathrm{~mol} / \mathrm{L}$ HNO3

Table-5: Heavy metal analysis

\begin{tabular}{|c|c|c|c|}
\hline Name of the Heavy Metal & Absorption Max $\boldsymbol{\Lambda}$ max & Result Analysis & Maximum Limit \\
\hline Mercury & $253.7 \mathrm{~nm}$ & 0.027 & $1 \mathrm{ppm}$ \\
\hline Lead & $217.0 \mathrm{~nm}$ & BDL & $10 \mathrm{ppm}$ \\
\hline Arsenic & $193.7 \mathrm{~nm}$ & BDL & $3 \mathrm{ppm}$ \\
\hline Cadmium & $228.8 \mathrm{~nm}$ & BDL & $0.3 \mathrm{ppm}$ \\
\hline
\end{tabular}

\section{Particle Size Determination by Microscopic Method} [8]

\section{Methodology}

Particle size determination was carried out by optical microscopic method. In which the sample were dissolved in the sterile distilled water (app $1 / 100^{\text {th }}$ dilution). Diluted sample were mounted on the slide and fixed with stage of appropriate location. Light microscopic image was drawn with scale micrometer to arrive at the average particle size. Minimum 30 observations were made to ascertain the mean average particle size of the sample.

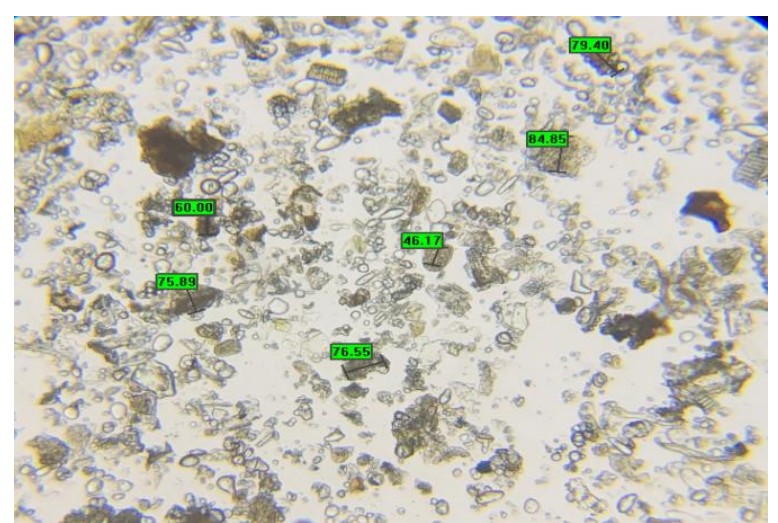

Fig-1: Microscopic Observation of Particle Size for the sample PC 


\section{REPORT}

Microscopic observation of the particle size analysis reveals that the average particle size of the sample PC was found to be $110.6 \pm 41.54 \mu \mathrm{m}$ further the sample PC has particle with the size range of lowest $46 \mu \mathrm{m}$ to highest $187 \mu \mathrm{m}$

\section{Phytochemical analysis of Parangichakkai Chooranam [7] \\ Test for alkaloids}

Mayer's Test: To the test sample, $2 \mathrm{ml}$ of mayer's reagent was added, a dull white precipitate reveals the presence of alkaloids.

\section{Test for coumarins}

To the test sample, $1 \mathrm{ml}$ of $10 \%$ sodium hydroxide was added. The presence of coumarins was indicated by the formation of yellow color.

\section{Test for saponins}

To the test sample, $5 \mathrm{ml}$ of water was added and the tube was shaken vigorously. Copious lather formation indicates the presence of Saponins

\section{Test for tannins}

To the test sample, ferric chloride was added, formation of a dark blue or greenish black color showed the presence of tannins.

\section{Test for glycosides- Borntrager's Test}

Test drug was hydrolyzed with concentrated hydrochloric acid for 2 hours on a water bath, filtered and the hydrolysate was subjected to the following tests. To $2 \mathrm{ml}$ of filtered hydrolysate, $3 \mathrm{ml}$ of chloroform was added and shaken, chloroform layer was separated and $10 \%$ ammonia solution was added to it. Pink color indicates the presence of glycosides.

\section{Test for flavonoids:}

To the test sample about $5 \mathrm{ml}$ of dilute ammonia solution was added followed by addition of few drops of conc. Sulfuric acid. Appearance of yellow color indicates the presence of Flavonoids.

\section{Test for phenols:}

Lead acetate test: To the test sample; $3 \mathrm{ml}$ of $10 \%$ lead acetate solution was added. A bulky white precipitate indicates the presence of phenolic compounds.

\section{Test for steroids:}

To the test sample, $2 \mathrm{ml}$ of chloroform was added with few drops of conc. Sulphuric acid $(3 \mathrm{ml})$, and shaked well. The upper layer in the test tube was turned to red and sulphuric acid layer showed yellow with green fluorescence. It showed the presence of steroids.

\section{Triterpenoids}

Liebermann-Burchard test: To the chloroform solution, few drops of acetic anhydride was added and mixed well. $1 \mathrm{ml}$ concentrated sulphuric acid was added from the sides of the test tube, appearance of red ring indicates the presence of triterpenoids.

\section{Test for Cyanins}

Anthocyanin:

To the test sample, $1 \mathrm{ml}$ of $2 \mathrm{~N}$ sodium hydroxide was added and heated for $5 \mathrm{~min}$ at $100^{\circ} \mathrm{C}$. Formation of bluish green color indicates the presence of anthocyanin.

\section{Test for Carbohydrates - Benedict's test}

To the test sample about $0.5 \mathrm{ml}$ of Benedict's reagent was added. The mixture was heated on a boiling water bath for 2 minutes. A characteristic colored precipitate indicates the presence of sugar.

\section{Proteins (Biuret Test)}

To extracts $1 \%$ solution of copper sulphate was added followed by $5 \%$ solution of sodium hydroxide, formation of violet purple color indicates the presence of proteins.

\section{Results of phytochemical analysis:}

The phytochemical analysis showed the presence of alkaloids, flavonoids, steroids, coumarin, phenol, tannin, protein, sugar.

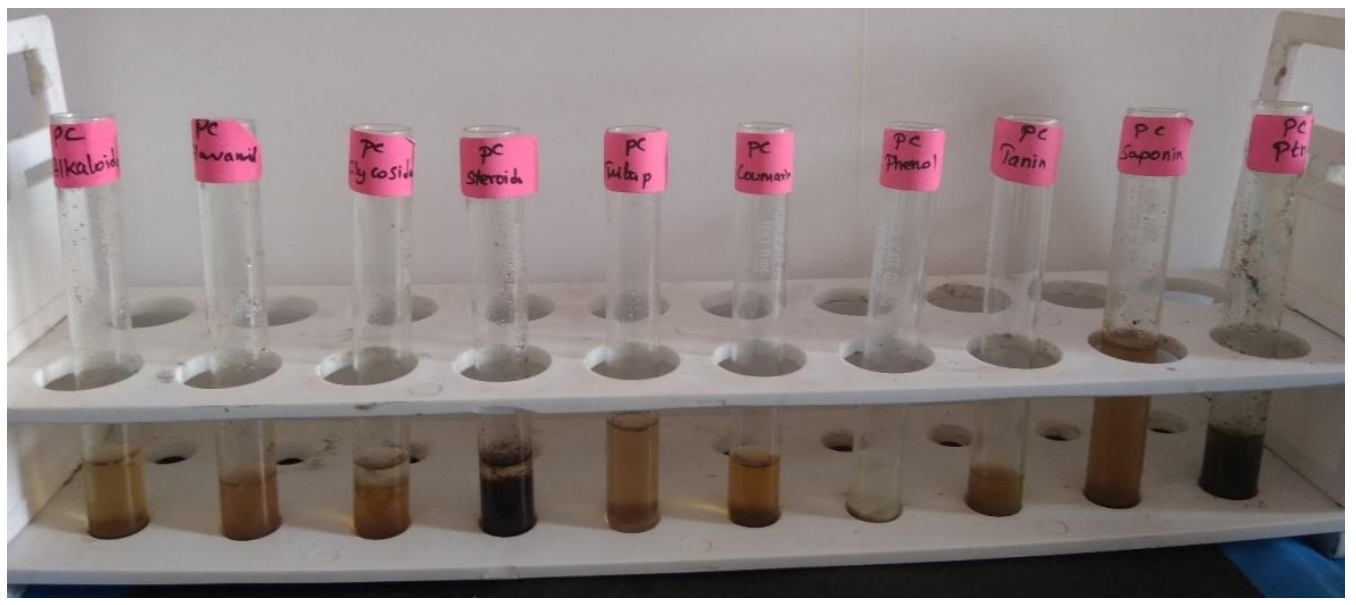

Fig-2: Qualitative Phytochemical Investigation 


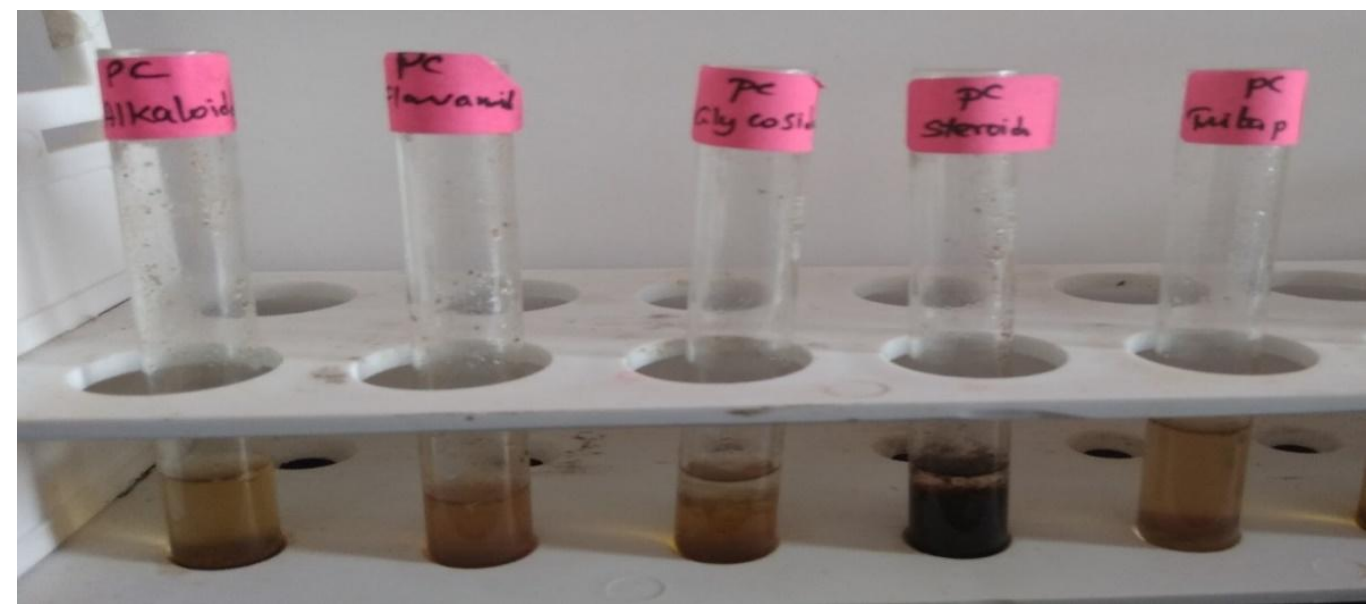

Fig-3: Test for Alkaloids, Flavonoids, Glycosides, Steroids and Triterpenoids

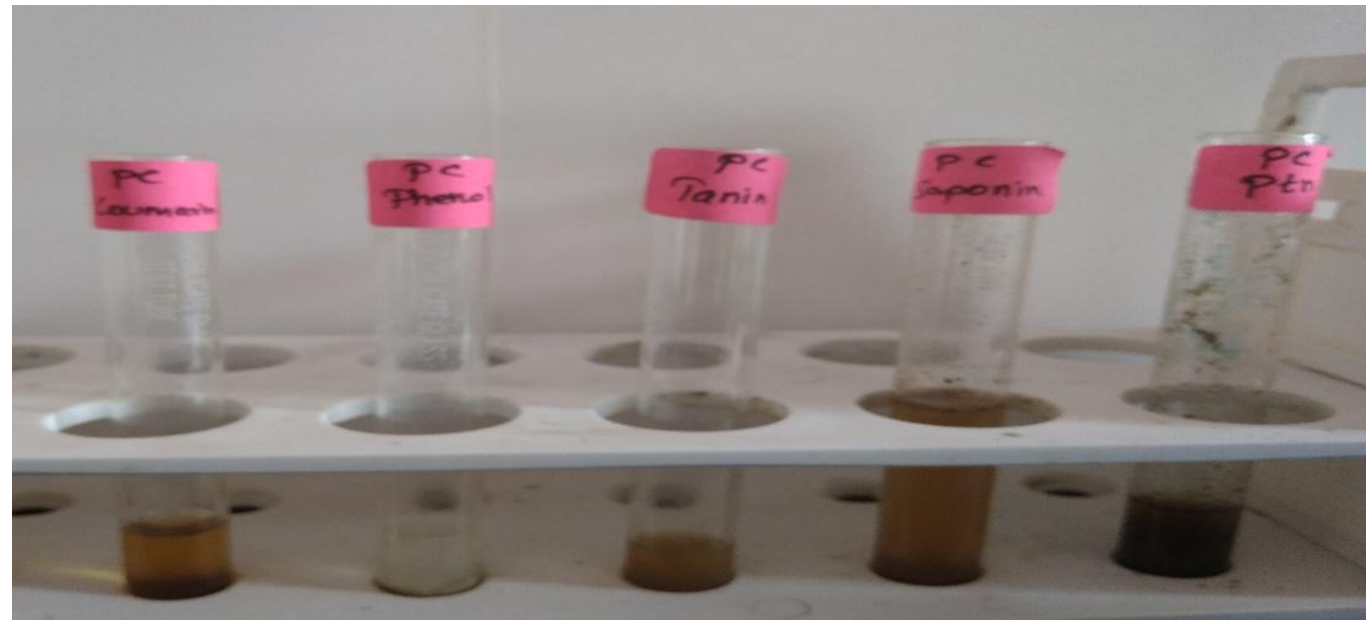

Fig-4: Test for Coumarin, Phenol, Tanins, Saponin, Proteins

\section{Biochemical analysis Parangichakkai Chooranam Preparation of Extract:}

$5 \mathrm{gm}$ of sample was taken in a $250 \mathrm{ml}$ clean beaker and added with $50 \mathrm{ml}$ of distilled water. Then it was boiled well for about 10 minutes. Then it was cooled and filtered in a $100 \mathrm{ml}$ volumetric flask and made up to $100 \mathrm{ml}$ with distilled water. This preparation was used for the qualitative analysis of acidic/basic radicals and biochemical constituents in it.

\section{Procedure:}

\section{Test for Silicate}

A $2 \mathrm{ml}$ of the sample was shaken well with distilled water.

\section{Action of Heat:}

A $2 \mathrm{ml}$ of the sample was taken in a dry test tube and heated gently at first and then strong.

\section{Ash Test:}

A filter paper was soaked into a mixture of extract and dil. cobalt nitrate solution and introduced into the Bunsen flame and ignited.

\section{Test for Acid Radicals}

Test for Sulphate:

$2 \mathrm{ml}$ of the above prepared extract was taken in a test tube to this added $2 \mathrm{ml}$ of $4 \%$ dil ammonium oxalate solution.

\section{Test for chloride:}

$2 \mathrm{ml}$ of the above prepared extracts was added with $2 \mathrm{ml}$ of dil. $\mathrm{HCl}$ until the effervescence ceases off.

\section{Test for Phosphate:}

$2 \mathrm{ml}$ of the extract were treated with $2 \mathrm{ml}$ of dil. ammonium molybdate solution and $2 \mathrm{ml}$ of con. $\mathrm{HNo}_{3}$.

\section{Test for carbonate:}

$2 \mathrm{ml}$ of the extract was treated with $2 \mathrm{ml}$ of dil. magnesium sulphate solution.

\section{Test for Nitrate:}

$1 \mathrm{gm}$ of the extract was heated with copper turning and concentrated $\mathrm{H}_{2} \mathrm{So}_{4}$ and viewed the test tube vertically down.

\section{Test for Basic radicals}

Test for lead:

$2 \mathrm{ml}$ of the extract was added with $2 \mathrm{ml}$ of dil. potassium iodine solution. 


\section{Test for copper:}

One pinch $(25 \mathrm{mg})$ of extract was made into paste with con. $\mathrm{HCl}$ in a watch glass and introduced into the non-luminous part of the flame.

\section{Test for Aluminum:}

To the $2 \mathrm{ml}$ of extract dil. sodium hydroxide was added in 5 drops to excess.

\section{Test for Iron:}

a. To the $2 \mathrm{ml}$ of extract was added $2 \mathrm{ml}$ of dil. ammonium solution

b. To the $2 \mathrm{ml}$ of extract $2 \mathrm{ml}$ of thiocyanate solution and $2 \mathrm{ml}$ of con $\mathrm{HNO}_{3}$ is added.

\section{Test for Zinc:}

To $2 \mathrm{ml}$ of the extract dil. sodium hydroxide solution was added in 5 drops to excess and dil. ammonium chloride was added.

\section{Test for Calcium:}

To $2 \mathrm{ml}$ of the extract was added $2 \mathrm{ml}$ of $4 \%$ dil. ammonium oxalate solution.

\section{Test for Magnesium:}

To $2 \mathrm{ml}$ of extract dil. sodium hydroxide solution was added in drops to excess.

\section{Test for Ammonium:}

To $2 \mathrm{ml}$ of extract $1 \mathrm{ml}$ of Nessler's reagent and excess of dil. sodium hydroxide solution were added.

\section{Test for Potassium:}

A pinch $(25 \mathrm{mg})$ of extract was treated off with $2 \mathrm{ml}$ of dil. sodium nitrite solution and then treated with $2 \mathrm{ml}$ of dil. cobalt nitrate in $30 \%$ dil. glacial acetic acid.

\section{Test for Sodium:}

2 pinches $(50 \mathrm{mg})$ of the extract was made into paste by using $\mathrm{HCl}$ and introduced into the blue flame of Bunsen burner.

\section{Test for Mercury:}

$2 \mathrm{ml}$ of the extract was treated with $2 \mathrm{ml}$ of dil. sodium hydroxide solution.

\section{Test for Arsenic:}

$2 \mathrm{ml}$ of the extract was treated with $2 \mathrm{ml}$ of dil. sodium hydroxide solution

\section{Miscellaneous \\ Test for Starch:}

$2 \mathrm{ml}$ of extract was treated with weak dil. Iodine solution.

\section{Test for Reducing Sugar:}

$5 \mathrm{ml}$ of Benedict's qualitative solution was taken in a test tube and allowed to boil for 2 minutes and added 8 to 10 drops of the extract was added and again boiled it for 2 minutes. The color changes were noted.

\section{Test for the Alkaloids:}

a) $2 \mathrm{ml}$ of the extract was treated with $2 \mathrm{ml}$ of dil. potassium Iodide solution.

b) $2 \mathrm{ml}$ of the extract was treated with $2 \mathrm{ml}$ of dil. picric acid.

c) $2 \mathrm{ml}$ of the extract was treated with $2 \mathrm{ml}$ of dil. phosphotungstic acid.

\section{Test for Tannic Acid:}

$2 \mathrm{ml}$ of extract was treated with $2 \mathrm{ml}$ of dil. ferric chloride solution.

\section{Test for Unsaturated Compound:}

To the $2 \mathrm{ml}$ of extract, $2 \mathrm{ml}$ of dil. Potassium permanganate solution was added.

\section{Test for Amino Acid:}

2 drops of the extract were placed on a filter paper and dried well. $20 \mathrm{ml}$ of Burette reagent is added.

\section{Test for Type of Compound:}

$2 \mathrm{ml}$ of the extract was treated with $2 \mathrm{ml}$ of dil. ferric chloride solution.

\section{Discussion AND Conclusion}

From the current study of Preclinical standardization of Parangichakkai chooranam which is mentioned in siddha texts shows that the drug parangichakkai chooranam was fine powder pale greenish brown in color with aromatic, slightly bitter and sweet taste. The drug size has particle size with the range of lowest $46 \mu \mathrm{m}$ to highest $187 \mu \mathrm{m}$. the loss on drying indicates the moister content of the drug was determined as $11.5 \pm 0.9 \%$. The total ash was found to be $14.3 \pm 1.054 \%$ which indicates inorganic content of the drug. The water-soluble extract was calculated as $5.213 \pm 0.91 \%$ and the value of acid insoluble as was found to be $0.066 \pm 0.041 \%$. the minimal level acid insoluble ash shows the less inorganic residue and alcohol soluble extract was found to be $13.8 \pm 2.553 \%$. in this trial drug water soluble extract was found to be more than the alcohol soluble extract. This increased water soluble extract may produce immediate drug action. The phytochemical analysis shows the drug has high polar secondary metabolites like alkaloids, flavonoids, steroids, coumarin, phenol, tannin, protein and sugar. In heavy metal analysis of mercury was 0.027 and lead, arsenic, cadmium was present within the below detectable limit there by ensures its safe usage. This study also relevels that the chooranam is sterile and free of bacteria, fungi and specific pathogen like E-coli, salmonella, staphylococcus aureus, pseudomonas aeruginosa. The Biochemical analysis of parangichakkai chooranam revealed the presence of sulphate, chloride, phosphate, carbonate, iron, arsenic and alkaloids. The above the analysis showed the sample description, physicochemical, phytochemicals and heavy metals. As a result, parangipattai chooranam was proved its safety over the defined standardization 
method. The results obtained could be utilized as reference for developing standard formulation.

\section{REFERENCE}

1. Pon K, Murugesa M. Text book of Balavagadam published by Indian System of Medicine and Homeopathy. 2016.

2. Kannuswami P. Text book of Scihitcha Ratna Deepam puplication. 2007: 116.

3. Murugesa M. Text book of Gunapadam Mooligai (part I) published by Indian System of Medicine and Homeopathy. $1^{\text {st }}$ edition. 1936.

4. Thiyagarajan R. Text book of Thathu Jeevam published by Indian System of Medicine and Homeopathy. 1952: 55.
5. India Pharmacopeia I Volume I, Government of India, Ministry of Health and Family welfare, Indian Pharmacopeia commission, 2014.

6. Pharmacopoeial Laboratory for Indian Medicine (PLIM) Guideline for standardization and evaluation of indian medicine which include drugs of Ayurveda, Unani and Siddha systems. Department AYUSH. Ministry of Health \& Family Welfare, Govt. of India.

7. Brain KR, Turner TD. The Practical Evaluation of Phytopharmaceuticals. Bristol: Wright Scientechnica; 1975:36-45

8. Takashi H. Measurement of Particle Size Distribution in Turbid Solutions by Dynamic Light Scattering Microscopy. J Vis Exp. 2017; (119): 54885. 